\title{
Integration of a community-based engagement model of service learning in a master's entry nursing program
}

Kim Amer, Elizabeth Aquino, Jonathan Handrup, Karen Larimer, Young Me Lee, Marisol Morales, Shannon Simonovich

School of Nursing, College of Science and Health, DePaul University, USA

Received: June 10, 2019

Accepted: July 9, 2019

Online Published: July 29, 2019

DOI: $10.5430 /$ jnep.v9n10p107

URL: https://doi.org/10.5430/jnep.v9n10p107

\begin{abstract}
The future of nursing will include a growing presence in communities with less focus on hospital health care. In response to the need for community health focused learning a five-course community engagement experience model was designed for the master's entry to nursing practice students in a nursing program. Community Engagement, defined as the process of working together in a collaborative spirit with groups of persons who are affiliated by geographic, special interest, or health care needs (CDC/ASTDR, 2006), is an ideal way for nursing students to fully understand the assets and needs of communities and develop goals for the health care concerns of specific communities. The goals of community engagement are to establish trust between clients, agencies, and the School of Nursing, to then develop mutual goals, enlist needed resources and improve learning and health outcomes in the community. This article describes the leveled objectives and course structure for the implementation of the community engagement pedagogy and model.
\end{abstract}

Key Words: Community engagement, Community-based engagement model, Community health, Nursing students

\section{INTRODUCTION}

To align our curriculum with our university's commitment to protecting, serving and empowering vulnerable persons, our School of Nursing developed a community-based engagement model of service learning (CbSL) with a focus on social determinants of health in the community. The Masters Entry to Nursing Practice (MENP) Program curriculum includes work with a community organization for two years and participation in a curriculum that provides learning focused on vulnerable populations using critical social theory. Critical social theory, as applied in our program, involves putting one into another's situation and exploring the stressors and health challenges in a vulnerable population.

The future of nursing will include a growing presence in com- munities with less focus on hospital health care. Community Engagement, defined as the process of working together in a collaborative spirit with groups of persons who are affiliated by geographic, special interest, or health care needs (CDC/ASTDR, 2006), is an ideal way for nursing students to fully understand the assets and needs of communities and develop goals for the health care concerns of specific communities. The goals of community engagement are to establish trust between clients, agencies, and the SON, to then develop mutual goals, enlist needed resources and improve learning and health outcomes in the community. ${ }^{[1]}$

The CBsL curricular integration in the School of Nursing brings alive a shared commitment to vulnerable populations and echoes the mission of our university's values centered

*Correspondence: Kim Amer; Email: kamer@depaul.edu; Address: School of Nursing, College of Science and Health, DePaul University, USA. 
on personalism, holism, and a commitment to making sure that students have opportunities for working with the disadvantaged and disenfranchised in society.

One aim for CbSL is to have students make connections between classroom learning with a focus on family models, community assessment and evaluation, and health promotion in individuals and communities. This aim leads to community-based learning that is focused on real-life health care delivery that takes place at community agencies. A second aim is for students to identify and challenge their assumptions about different populations as well as expand their worldview. The Pew commission, as early as 1998, recommended that nursing programs include community-based service learning. ${ }^{[2]}$ The implementation of long-term partnerships with community agencies, although ideal, is not easy to develop and sustain. After the work of identifying community partner sites and setting up contracts are established then faculty, students, and community partners help sustain the partnerships. The pedagogy of the city and community as classroom is powerful and can be life altering for students. Students experience unique cultures, environments, physical and administrative structures oftentimes in settings that have fewer physical resources than are present in the hospital setting. This article describes integration of CbSL into a MENP curricular sequence and discussion of CbSL as a mechanism for students to enhance their learning through community engagement experiences.

\section{OVERVIEW OF CBSL IN THE MENP PRO- GRAM}

In Fall 2012, the SON adopted CbSL as a curricular innovation in its MENP Program. Students are assessing community needs and use the experiences to think about the broader population health issues. Learning objectives include scaffolded and structured reflections align with these objectives and are used in this pedagogical model. The hope is that student learning will emerge that can only be gained outside of the classroom.

This pedagogy is also supported by the Pew Health Professions Commission's recommendation that nursing programs include CbSL. ${ }^{[2]}$ Distinct from the students' nursing clinical practice experience, the CbSL experience gives students an awareness of an individuals' experiences, challenges and lived environment. Students also apply the social and physical determinants of health in a community as emphasized in Healthy People 2020. ${ }^{[3]}$ In addition, it provides students the opportunity for self-reflection on their assumptions about the community and challenges their own worldview.

This curricular innovation of community engagement was fa108 cilitated through the SON's partnership with a campus center that develops mutually beneficial relationships between community organizations and the university, whose staff identify appropriate community partners to host the nursing students and assist faculty in the development and integration of $\mathrm{CbSL}$ into their curricula to meet the course and CbSL objectives. Currently, each student completes 112 hours of CbSL over 7 quarters of an 8-quarter curriculum. By partnering with the same community organization for all 7 quarters, it allows a deepening of the relationship and experience that can only occur over time.

Some of the potential benefits of CbSL to nursing students that have been discussed in the literature include fostering respect for others, ${ }^{[4]}$ promoting professional communication, ${ }^{[5]}$ exposure to diverse populations, ${ }^{[4]}$ experience with complex challenges that require prioritization skills, ${ }^{[6]}$ opportunity to practice leadership skills, ${ }^{[7]}$ and modeling of professional conduct. ${ }^{[7]}$

\section{MAIN PURPOSE AND SETTING}

The purpose of the curricular innovation was to integrate $\mathrm{CbSL}$ into the MENP. Going beyond the usual single-course experience, the CbSL pedagogy includes a longer-term relationship between the student and the community organization. Typical community engagement experiences in nursing programs are short-term experiences like that described by Kazemi, Behan \& Boniauto (2011). ${ }^{[8]}$ While limited experiences, such as a single-term community experience for less than 10 weeks, are good for increasing awareness of community issues and establishing a context for communities in need of nursing interventions, it provides little time to develop a significant relationship with the partner organization. In contrast, extended community engagement models expand the opportunity for students to become more participatory, potentially involved in needs assessment and the designing of interventions and programming. Learning experiences in the SON CbSL are aimed at an analysis of the community and developing creative solutions resulting in a sustainable capstone project.

\subsection{Model of community engagement in the school of nursing}

There are many different definitions of service, service learning, and community engagement. The American Nurses Association Social Policy Statement defines service as the establishment of a caring relationship that facilitates health and healing (ana.org). Definitions are focused on collaborative interactions between students and community workers. Service learning is a nursing activity that can be categorized as a therapeutic nursing intervention. Even though service learn- 
ing is not the traditional inpatient therapeutic nursing, it is a critical component of nursing care. Callister and HobbinsGarbett (2000) ${ }^{[2]}$ discuss service learning as "an effective, dynamic, and engaging way to learn because students apply classroom content and readings in community-based clinical practice." Service learning and community engagement in the CESON are defined as a reciprocal interaction with mutual goal setting and respect. The School of Nursing's philosophy is that students, clients, and agency personnel should all have equal status and all participate in goal setting and development of health promotion in individuals and the community.

Nurse Educators have described integration of service learning in specific courses, but not throughout a full curriculum. Kazemi, Behan \& Boniauto (2011) ${ }^{[8]}$ described integration of community-based service learning through preceptorships in a community health clinic with positive student awareness of community health needs and learning about diverse populations. Callister \& Hobbins-Garbett $(2000)^{[2]}$ described positive student personal satisfaction, higher level critical thinking skills, increased awareness for community health needs and a greater capacity for connectedness in a women's health class community service experience. The CESON is an integrated five-course curricular model that focuses on broader issues of population health concepts and critical social theory with hands on experiences.

The design of the Community Engagement in the School of Nursing (CESON) model emerged from years of discussion about living the mission of the university with the goal of coordination of long-term meaningful community health partnerships. Students in the SON in past years had a variety of experiences doing community-based service learning, however it was rarely more than 10 weeks at a time with less than 20 hours of service time. Several discussions in past years focused on the concept of long term sustainable partnerships with community sites throughout the curriculum, however the implementation was never executed.

In the fall of 2012, as part of conversations between the nursing faculty and the university's Community-based Service Learning and Community Service Studies, an endowed community-based service learning center within the university, established community sites for student learning. The goal was for all students at the university to learn through experiencing the communities of our major metropolitan area.

After many meetings and approval by the SON faculty, the preliminary model for service learning curriculum integration was created to ensure mutually beneficial relationships through multi-quarter placements at community sites. Courses integrate reflections and assignments that incorporate higher order learning over time including first describing the community and the organization and then toward the last course analyzing public policy and the effect on vulnerable populations. Courses were chosen that have a logical connection to the goals of service learning and where meaningful integration between community-based learning and classroom instruction could happen.

The following CESON model (see Table 1) depicts how we have envisioned the ladder of engagement for MENP students:

Table 1. Scaling of curricular objectives throughout program in CESON

\begin{tabular}{|c|c|c|c|c|}
\hline & $\begin{array}{l}\text { N431: Health Promotion for } \\
\text { Families and Communities }\end{array}$ & $\begin{array}{l}\text { N400: Nursing } \\
\text { Theories }\end{array}$ & $\begin{array}{l}\text { N302: Art \& Science of } \\
\text { Nursing II }\end{array}$ & $\begin{array}{l}\text { N303: Art \& Science of } \\
\text { Nursing II }\end{array}$ \\
\hline $\begin{array}{l}\text { Nursing } \\
\text { Activities }\end{array}$ & Assess Community & $\begin{array}{l}\text { Explore Population } \\
\text { Health Issues }\end{array}$ & $\begin{array}{l}\text { Implementation of } \\
\text { Community Based } \\
\text { Intervention }\end{array}$ & $\begin{array}{l}\text { Co-create solutions } \\
\text { based on evaluation of } \\
\text { intervention }\end{array}$ \\
\hline $\begin{array}{l}\text { Leveled } \\
\text { Objectives }\end{array}$ & $\begin{array}{l}\text { Raise Awareness } \\
\text { Gain Knowledge }\end{array}$ & $\begin{array}{l}\text { Analysis of global } \\
\text { health issues affecting } \\
\text { community }\end{array}$ & $\begin{array}{l}\text { Create Individual nursing } \\
\text { interventions and } \\
\text { evaluation plan }\end{array}$ & $\begin{array}{l}\text { Synthesize data from } \\
\text { intervention and } \\
\text { evaluation }\end{array}$ \\
\hline $\begin{array}{l}\text { Theoretical } \\
\text { Basis }\end{array}$ & Social Ecology & Critical Social Theory & Nursing Process & Innovation in Nursing \\
\hline
\end{tabular}

Course sequence - scaffolding the engagement and the learning In an attempt to have students build long-term relationships and engagement projects, one course per 10-week quarter was selected throughout the MENP curriculum that would have a service learning component. This helped to ensure scaffolding of the learning and engagement experience and the ability to build relationships with the community partners. Each designated course requires 16 hours of service learning. The first course is a community health and health promotion course and reflects a logical connection. The students orient in their community sites during the first course. The following courses have connections with community service in 
more theoretical, political, and philosophical ways. Service learning is used as a "transformative critical pedagogy. ${ }^{[9]}$ For example, in Theoretical Components in Nursing there is an analysis of nursing concepts and theories and emerging content integrating social justice ${ }^{[9]}$ and critical social theory through analysis of the communities they are engaging with. Students develop their own worldview based on their experiences in the community sites and their individual perspectives. Each course includes reflections and assignments that relate service learning to course objectives.

This model is unique because of the nature of the master's entry to nursing practice program. Students have had job experiences and life experience prior to starting the program. The students are able to learn quickly and arrive at an analysis and synthesis level more quickly than traditional undergraduates. This model also raises awareness regarding the complexity of persons in the community. When the students work with patients in the hospital they should be able to expand their view to the communities their patients return to and the unique health needs the patient may have related to the community. Lipman (2017) ${ }^{[11]}$ describes the need for pediatric nurses to be aware of the patient and family's community since social determinants of health account for $75 \%$ of the chronic illness challenges that children face. The engagement in communities should be a requirement for all nursing students.

\section{Logistics of CbSL}

The curricular model integration would not have been possible without the collaboration with the university's Center for Community-based Service Learning. They identify community partners for graduate level service learning course placements and work with the Nursing community engagement coordinator in the SON and faculty to provide logistical support, in-class reflections when requested, and faculty development workshops to prepare service learning faculty to provide high quality service learning integration into their academic course. The center also helps coordinate community site visits for faculty and students as well as other types of support for community partners, faculty, and students that may arise throughout the quarter.

This CESON plan includes 16 hours of service learning per identified course listed in Table 2. The community partner engages with the student and develops the student's research project. The coordination of service sites for cohorts of more than 50 students can been challenging for the SON partner, the Center for Community-based Service Learning, and the community sites. However, the placement and coordination challenges have begun to resolve as the list of community partner sites grows, strong partnerships develop, and the value of CbSL is acknowledged by all parties.

Table 2. Stages of higher order learning in CbSL staged objectives for the CESON model implementation with courses

\begin{tabular}{|c|c|c|c|}
\hline Awareness & Analysis & Application & Innovation \\
\hline $\begin{array}{l}\text { Course: Health Promotion in } \\
\text { Families and Communities } \\
\text { Assignment: } \\
\text { Community assessment }\end{array}$ & $\begin{array}{l}\text { Activities that enhance an } \\
\text { understanding of community } \\
\text { health issues and drives } \\
\text { deeper perspectives about the } \\
\text { role of nursing in the US } \\
\text { health care system. }\end{array}$ & & \\
\hline $\begin{array}{l}\text { Course: Theoretical Foundations for } \\
\text { Nursing } \\
\text { Assignment: } \\
\text { Theory to practice presentation } \\
\text { applies to community site }\end{array}$ & & $\begin{array}{l}\text { Application of concepts and } \\
\text { theories of advanced nursing } \\
\text { knowledge \& professional } \\
\text { practice for the benefit of the } \\
\text { community }^{[10]}\end{array}$ & \\
\hline $\begin{array}{l}\text { Course: Art and Science of Nursing: } \\
\text { Psychiatric Nursing } \\
\text { Assignment: Creative community } \\
\text { support solutions }\end{array}$ & & $\begin{array}{l}\text { Reflection on community } \\
\text { psychiatric needs }\end{array}$ & $\begin{array}{l}\text { Create education } \\
\text { interventions and long } \\
\text { term educational health } \\
\text { promotion materials }\end{array}$ \\
\hline
\end{tabular}

The SON identifies the logistics of establishing relationships and supervision of students for community sites for the MENP to integrate service learning, encourages service learning faculty to attend site visits and pertinent faculty development workshops, and works with the center to ensure high quality mutually beneficial service learning in the MENP courses. Service-learning outcomes are incorporated into the learning outcomes for the course and faculty collect 
logged hours from students and lead reflections on CbSL in each course. This brings the experience of community engagement to a higher level of understanding on a systems level.

The community partner identifies meaningful service opportunities that MENP students participate. There is a progressive relationship of service and learning that is developed during the student's placement site. The community partner communicates with the Center and/or Nursing faculty regarding the progress of the students. The community partner identifies a site representative that can serve as the students' on-site supervisor. The community partner works with the student and Center to identify mutually beneficial service and learning projects.

The MENP students follow the university's community conduct and safety guidelines, meet the expectations of the course and the community partner, and work with the community partner to identify mutually beneficial service and learning projects. Evaluation and assessment are conducted continually throughout the program to ensure on-going success, as determined by the evaluations of students, faculty, and community sites, and adherence to learning outcomes and standards.
Presently the evaluation data is being collected and analyzed. The next article written will include the evaluation results. Anecdotal comments from students during reflections in courses range from raising their awareness regarding the challenges within a vulnerable population to expanding their view of health beyond the physical needs of patients including application of social ecological theory. When the students first arrive at the community site they are somewhat unsure about the benefit. After the program students comment that they were enriched and enlightened by the experience.

\section{Conclusion}

This article described an innovative approach to community engagement for graduate level nursing students in a MENP Program, including the curricular development and the implementation steps. The model of higher order learning, systems thinking, population health concepts and intersectional and critical and emancipatory nursing theory has demonstrated that $\mathrm{CbSL}$ can be a possible curricular innovation for graduate nursing program fostering and supporting social justice practices.

\section{CONFlicts OF INTEREST Disclosure}

The author declares that there is no conflict of interest.

\section{REFERENCES}

[1] Jabbar AM, Abelson J. Development of a framework for effective community engagement in Ontario, Canada. Health Policy. 2011; 101(1): 56-59. PMid:20863588 https://doi.org/10.1016/j. healthpol.2010.08.024

[2] Callister LC, Hobbins-Garbett D. "Enter to Learn, Go Forth to Serve" Service Learning in Nursing Education. Journal of Professional Nursing. 2000; 16(3): 177-183. PMid:10860316 https: //doi.org/10.1053/PN.2000.6177

[3] Healthy People 2020. June 6, 2014. Available from: http://www .healthypeople.gov/2020/topicsobjecti ves2020/overview . aspx?topicid $=39$

[4] Blackwell C. Meeting the Objectives of Community-based Nursing Education. In Amber Dailey-Herbert, Emily Donnelli Sallee \& Laurie N Dipadova Stocks (Eds). Service-eLearning: Educating for Citizenship. Charlotte North Carolina, Information Age Publishing; 2008.

[5] Reams P. Service Learning in Health Care Higher Education: Risk or Not to Risk. Education For Health: Change In Learning \& Practice (Taylor \& Francis Ltd). 2003; 16(2): 145. PMid:14741900 https://doi.org/10.1080/1357628031000116835

[6] Jackson C, Leadbetter T, Manley K, et al. Making the complexity of community nursing visible: the Cassandra project. British Jour- nal of Community Nursing. 2015; 20(3): 126-133. PMid:25754780 https://doi.org/10.12968/bjcn.2015.20.3.126

[7] Foli KJ, Braswell M, Kirkpatrick J, et al. Development of leadership behaviors in undergraduate nursing students: A service-learning approach. Nursing Education Perspectives. 2014; 35(2): 76-82. https://doi.org/10.5480/11-578.1

[8] Kazemi D, Behan J, Boniauto J. Improving teaching strategies in an undergraduate community health nursing $(\mathrm{CHN})$ program: Implementation of a service-learning preceptor program. Nurse Education Today. 2011; 31(6): 547-52. PMid:21071114 https: //doi.org/10.1016/j.nedt.2010.10.024

[9] Carnicelli S, Boluk K. The promotion of social justice: Service learning for transformative education. Journal of Hospitality, Leisure, Sport \& Tourism Education: Part B. 2017; 21: 126-134. https : //doi.org/10.1016/j.jhlste.2017.01.003

[10] Sheafer V. Using Service Learning to Teach Classic Learning Theories. Psychology Journal. 2014; 11(2): 77-82.

[11] Lipman T. Community engagement for pediatric nurses: No longer a choice. Journal of Pediatric Nursing. 2017; 33: 101-102. PMid:28073621 https://doi.org/10.1016/j.pedn.2016.12 .014 